\title{
Discussion on the Inheritance, Integration and Promotion of Chinese Traditional Folk Music Culture in College Piano Education
}

\author{
Jie Luo \\ College of Music and Dance \\ Sichuan Minzu College \\ Kangding, 626001, Sichuan, China \\ Email: luoojjie@sina.cn
}

\begin{abstract}
China has a long and influential musical tradition based on the philosophy and culture of ancient China. Chinese folk music is considerably different from western traditional music, paying more attention to the form expression as well. At present, the pedagogy and didactic materials used in Chinese college piano teaching are primarily from the western educational system, so that many students have produced a wrong idea that the West is always better, largely ignoring Chinese traditional culture and folk music in piano learning. Here, we highlight the importance of inheriting and integrating the traditional folk music culture of our country into the western piano educational system in colleges and universities. We also explore strategies, techniques and concepts involved in the integration, discuss the cultural difference and blending between the China and the West, and give a prospect in future Chinese college piano education.
\end{abstract}

Keywords: Chinese folk music; traditional culture; college piano education; western educational system; cultural heritage

\section{INTRODUCTION}

The Chinese traditionally believe that sound influences the harmony in the universe. China has a very unique take on the meaning of music, not seeing it as an art form designed for entertainment until very recent times for a country with such an enormous history. However, its forms of traditional folk music still exist while they have been influenced by western music over the past decades [1]. As an important aspect of the musical art, piano art would also be valuably inseparable from the nourishment of Chinese traditional music culture. From the beginning of "March of Peace" created by Mr. Yuanren Zhao in 1915, the piano music composition in China has a history of 100 years [2]. Since then, Chinese piano artists have addressed great efforts to inherit and integrate our traditional folk music culture in piano art. The continuous exploration by Chinese musicians substantially widens the border of piano music culture and effectively promotes the development of piano art in the world; they also introduce new elements and vitality to the piano performance [3]. On the other hand, however, the piano teaching in Chinese colleges and universities has long been typically using the didactic methods and materials from western educational system, but largely ignoring the inheritance of our traditional music culture. Folk music is a core aspect of Chinese music art and an important symbol of our national characteristics. We therefore should fuse and integrate the Chinese traditional folk music culture into western educational system in college piano teaching [4]. This is particularly significant for the cultivation of piano artists and educationists with Chinese national characteristics.

\section{CURRENT STATUS OF CHINESE FOLK MUSIC IN COLLEGE PIANO EDUCATION}

\section{A. Significance of Chinese Folk Music Culture in Colleges}

China has a variety of ethnic groups and a diversity of folk music [5]. For the college piano educators, we can absorb nutrition from the folk music culture of different ethnicities to guarantee our taught music with vitality and artistic charm, and to get more and more people's attention and love it. Chinese traditional culture is a fertile artistic soil, and lack of its nourishment the college music education is like a tree without root. For college piano teachers and students, they should accept and pay attention to traditional music culture, and fuse Chinese folk music into western teaching materials and spiccato techniques. In addition, teaching of folk music in colleges and universities is the key to carrying forward the excellent culture of our country to students who learn and play western musical instruments. As the important place of music education, colleges and universities have good student resource and unique educational environment, and should strengthen the cultivation of students with learning, inheritance and development of Chinese traditional folk music culture.

\section{B. Lack of Chinese Folk Music Culture in Colleges}

At present, piano teaching in China is still dominated by the pedagogy from western educational system. With the development and emphasis of Chinese folk music in recent years, the traditional music culture is continuously integrating with piano art [6]. Folk music has gradually become one of the contents of piano teaching in Chinese colleges and universities. However, traditional culture in the piano teaching is still not placed at an important position. Although Chinese colleges and universities have added some folk music to the piano teaching materials, such as the classic folk songs "the longing for the moonlight", "dongfang hong" and "the love song in Kangding" and so on, but most are adapted repertoires, lacking of originality. On the other hand, because of the origin of the piano in Europe, the development of western piano education has its long history and rounded system. There are systematic textbooks and numerous music 
materials and etudes from enlightenment to advanced stage. Therefore, most of the piano teachers in China tend to teach students using the western educational system [7]. However, teachers would have great influence on the students who have not yet formed their own music style. Currently, college piano students can only contact Chinese folk music very limitedly, so it is difficult to understand the traditional culture of Chinese nation.

\section{Reasons for the Lack of Chinese Folk Music Culture in Colleges}

The disadvantaged status of folk music lack in piano teaching is mainly reflected in three aspects: (1) The original etudes are rare; many famous musicians have created or adapted the folk music for piano teaching, there are only few songs available for piano teaching, most of them are adapted, and (2) the teaching of folk music in college piano educational system is not incomplete. It is hard to establish a systematic teaching framework in the short history of Chinese piano education. Currently, the western piano educational system is still dominated in our colleges and universities, and the participation of traditional culture and folk music is very limited. Some piano teachers are not aware of their responsibility for not only technical teaching but also cultural heritage.

\section{PROMOTION OF CHINESE FOLK MUSIC CULTURE IN COLLEGE PIANO EDUCATION}

\section{A. Cultivation of Students with National Consciousness and Nationalism Emotion}

The primary stage of the teaching of piano music in colleges and universities needs to introduce classic folk music to the classroom, which will familiarize students with the folk music and to cultivate students' interest in the traditional music. First, the college piano teachers should have a national consciousness and the accumulated culture In this way, teachers can pass on the cultural charm and display the connotation of folk music through teaching to students, and let the students feel the value and splendor of Chinese folk music. Only the teachers who have national consciousness and comprehend traditional culture can teach students with the consciousness and culture. Second, students should be set up with a correct view that the integration of Chinese folk music in piano learning does not mean to abandon the western educational system. Instead, the traditional culture should be integrated into the western system to promote the development and nationalization of college piano education in China. Third, piano teachers should gradually increase traditional culture and folk music in the different learning stages of students, especially at the beginning stage, the teachers could choose some simple piano pieces adapted from the classic melodies, and also try to arouse the students' interest in folk music. The primary stage of learning piano is to establish a strong national consciousness and lay a solid cultural foundation for the folk music in future piano learning.

\section{B. Cultural Blending between Western Piano Education and Chinese Folk Music}

College piano education in China should combine the current higher art education model to create more music pieces containing traditional culture, and then enrich the content of piano teaching with folk music. These traditional music works can be arranged and classified to generate a scientific system of piano teaching that integrates Chinese folk music into western piano education [8]. In addition, the traditional folk music culture should be strengthened for not only piano teachers and learners but also all college students. The Chinese modern music artists should be encouraged to create more music working with traditional elements and to pay more attention to promote the traditionalization and nationalization of college piano education in China.

\section{Highlighting the Importance of Chinese Folk Music in College Piano Education}

Traditional music is the unique aesthetic standard of music in China and represents Chinese traditional culture and spirit, which plays an important role in the formation of national thinking habits and aesthetic consciousness. The theory of traditional music plays an important role in modern music teaching, and reflects the natural characteristics of our nation. Chinese folk music is a core constitution of traditional music. The application of Chinese folk music in piano teaching in colleges and universities plays a significant role in guiding piano teaching and practice. Commonly, the piano is a classic tool for the presence of western music pieces. The combination of Chinese traditional culture and folk music will highlight the artistic expression of piano music, as well as an essential aspect of cultural blending between East and West. The main purpose of college piano music teaching is to train musicians and music teachers, who should pay attention to theoretical innovation and cultural heritage. Chinese folk music is rich in subject matter and suitable for creating a large number of musical works. The folk music is derived from the traditional music melody, and deducted through the form of the piano will give the music a more new artistic charm. The teaching process of piano music in colleges and universities can be based on our national tones and the characteristics of traditional music culture, so that it can be more perfect in techniques, make the piano music pieces with traditional cultural characteristics and fully reflect the nature of the times. Compared with the West, the piano didactic materials regarding Chinese folk music are very limited and cannot provide a systematic supporting for the piano educational system, which largely restricts the development of the piano nationalization. Therefore, the integration of Chinese folk music theory into existing piano didactic materials and grading these materials enable to form a scientific piano educational system. A large number of Chinese folk music theories can be applied to piano teaching in colleges and universities to create more piano music pieces with national characteristics. Improvement of the cognitive level of traditional music as well as systematic arrangement, dissemination and inheritance of Chinese folk music culture in the piano teaching will lay a solid foundation for the development of traditional folk 
music in China. Different nationalities have different cultural characteristics, and they also create different musical cultures. Chinese traditional folk music is an important member of the world music culture family, which reflects the characteristics of Chinese culture from different ethnic folk music. Therefore, the integration of Chinese folk music into piano teaching in colleges and universities can make us better understand the development of music.

\section{Paying Attention on the Reform of College Piano Education}

The piano education in colleges and universities is an educational stage that most piano artists should experience. The stage of undergraduate education will take the piano students from a step of emphasis on a single major study and bring into the condition of systematic study. Students will accept a lot of basic theories and knowledge of music in the lessons, learn about the difference and similarity between the music cultures and histories of Chinese and West, and train their solfeggio, execution skill and so on from the musical accomplishment. It is also the accumulation of music and cultural accomplishment of the professional pianists and piano educators. Therefore, the piano education is a core aspect of music education in colleges and universities. With the continuous development of Chinese art, higher art educational system is also optimized. In order to cultivate more outstanding piano artists, our country is committed to cultivating a number of persons with artistic ability to contribute to art education in our country. First of all, under the mode of higher art education, piano music education takes piano music as its carrier and expression form. Chinese piano education needs to create more music pieces involving Chinese traditional culture, thus enriching the teaching content of folk piano music. The systematic and scientific educational system of piano music encourages the wide application of folk music in the teaching of piano in colleges and universities. At the same time, we should encourage the modern musicians to compose more piano music works with modern elements, so that the piano teaching in colleges and universities will be closely connected with the times, and the piano educational system will be improved substantially. Piano teaching in higher art education is based on the technical basis of piano to train piano musicians with national characteristics The first is to pay attention on experiential teaching. For different periods, different styles and different national characteristics of piano music, teachers should guide students to understand the skill and technique of playing folk music in many aspects, such as rhythm, emotion, spirit and so on. Teachers should choose the appropriate contents and didactic materials to release the musical potentiality of students with creative thinking. For example, it is needed to carry out a piano adaptation competition, to encourage teachers to give piano concerts at different times, and to provide students with more improvisational performances and home and stage. The opportunity of the exchange of famous music colleges and universities to stimulate students creative ability; at the same time set up accompaniment and ensemble courses to guide students to accompany the chorus, dance, vocal music, instrumental music and other forms with piano accompaniment, that is, to practice students with traditional music culture and to cultivate students who can perform in various forms of art ability.

\section{CONCLUSION}

Chinese folk music is not only highly artistic, but also an important section of our traditional culture, bearing the responsibility for heritage of Chinese culture. This inheritance could cultivate students to have national consciousness, to absorb good traditional culture for the future piano learning. With current educational reform we should pay more attention to teaching experience and to providing more opportunities for piano students to practice in folk music [9]. Based on the rounded system of western piano education we could create a piano teaching mode with Chinese characteristics by combining the current situation of piano teaching in China and traditional folk music culture, thus promoting the further development of Chinese music and art, and showing the charm of the ancient culture of our country through piano music and opening a window of "Chinese culture" to the world.

\section{ACKNOWLEDGMENT}

This work is supported by the General Project of Sichuan Provincial Department of Education (No. 18SB0511) and the Project of Sichuan Minzu College (No. 2017xjjg44).

\section{REFERENCES}

[1] Jin Jie. Chinese music. Cambridge: Cambridge University Press, 2011.

[2] Qian Yu. Impressionistic music features in Chinese piano works Cross-Cultural Communication, 2014, 10(6), pp. 195-205.

[3] Xueming Hong. The study of the embodiment of Chinese traditional culture in piano works. Song of the Yellow River, 2016 , 455(2), pp. 117

[4] Meng Wang. Research on folk music of piano teaching in colleges and universities. Home Drama, 2016, 222(2), pp. 81-82.

[5] Miriam Lang. Folk music of China: living instrumental traditions. The China Journal, 1997, 38(5), pp. 207-209.

[6] Ruyi Hu. The origin of Chinese piano culture. Academic Exploration, 2012, 148(3), pp. 186-188.

[7] Changkui Wang. Professional piano education in Chinese piano music culture. International Education Studies 2010, 3(1), pp. 92-95.

[8] Yaqin Luo. Exploration on traditional folk music of college piano education. Home Drama, 2016, 225(5), pp. 204.

[9] Changkui Wang. Review and thinking of piano teaching in China's higher normal school. Asian Social Science 2009, 5(7), pp. 23-28. 